\title{
AZ ALBÁNIAI MUSZLIMOK TÖRTÉNETE ÉS AZ ISZLÁM HÁZASSÁGI JOGHOZ VALÓ VISZONYUK A NEMZETI IDENTITÁSUK TÜKRÉBEN
}

\author{
The History of Muslims in Albania and their Relationship to \\ Islamic Marriage Law in the Light of their National Identity
}

\author{
Baranyi Emese Zsuzsanna ${ }^{1}$
}

\begin{abstract}
Absztrakt: Az európai iszlám vizsgálatakor különleges színfoltot jelentenek a Balkán muszlim többségű országai, ahol már évszázadokkal ezelőtt meghonosodott a vallás. Tanulmányomban arra keresem a választ, hogy az albániai muszlimok az ország történeleme során betöltött szerepe milyen hatással lehetett a nemzeti identitásukra, a vallási életükre és az iszlám házassági joghoz való viszonyukra. A Nyugat-Európában élő muszlim népesség kapcsán egyre többet hallhatunk az iszlám családjogi szabályok alkalmazásának lehetôségeirôl egy multikulturális társadalom keretein belül. A nyugat-európai muszlim közösségekkel szemben Albániában eddig nem jelentkezett arra igény, hogy az iszlám családjog alkalmazására külön rendszert állítsanak fel. Ennélfogva az iszlám házassági jogot meglehetősen tágan értelmezik. Ennek oka valószínúleg elsősorban az ország kommunista múltjából következik. Albániában a tradicionális vallási felekezetek, vagyis a muszlimok, a római katolikusok és az ortodox keresztények között jellemzően magas fokú tolerancia tapasztalható. Az 1990-es évek végére megvalósuló albán laïcité, vagyis a szekularizált államberendezkedés az állam és az egyházak közötti kölcsönös együttmúködésen, az összes vallási közösség egyenlőségének tiszteletben tartásán és a közjó fenntartásán alapszik. Az albániai muszlimok kerülik az állami joggal való konfrontálódást, ennek ellenére az utóbbi bő évtizedben az albán politikai elit egy része
\end{abstract}

1 A szerzőről: Baranyi Emese Zsuzsanna a Szegedi Tudományegyetem Állam- és Jogtudományi Kar Doktori Iskolája, Összehasonlító Jogi és Jogelméleti Intézet PhD hallgatója Elérhetősége: emesezsu.baranyi@gmail.com A szerzô további publikációi az alábbi hivatkozáson érhetők el:

https://m2.mtmt.hu/gui2/?type=authors\&mode=browse\&sel=authors 10066396 
iszlám-ellenes retorikát kezdett alkalmazni, amely identitásdilemmához vezetett az albániai muszlimok körében.

Kulcsszavak: albániai muszlimok, iszlám házassági jog, vallási tolerancia, nemzeti identitás

Abstract: The Muslim-majority countries of the Balkans, where the Islamic religion was established centuries ago due to the spread of the Ottoman Empire, represent a special topic within the research of European Islam. In my study, I investigate how the role of Muslims throughout Albania's history has affected their national identity, religious life and relationship to Islamic marriage law. The possibilities of applying Islamic family law within a multicultural society is a frequent subject of public discourse regarding the Muslim population in Western Europe. Unlike in Muslim communities in Western Europe, though, there has been no demand in Albania for a special application of Islamic family law. Albanian Muslims interpret Islamic marital law in a not very strict sense. The reasons for this probably stem from the country's communist past. It is also an important cultural factor that there is a high degree of tolerance among traditional Albanian religious groups, i.e. Muslims, Roman Catholics and Orthodox Christians. Albanian secularism, realized by the end of the ' $90 \mathrm{~s}$, is based on mutual cooperation between the state and churches, respect for the equality of all religious communities, and the maintenance of the public good. Muslims in Albania avoid confrontation with state law; nevertheless, some members of the Albanian political elite have begun to adopt an anti-Islamic rhetoric over the last decade, leading to an identity dilemma among Muslims in Albania.

Keywords: Muslims in Albania, Islamic marital law, religious tolerance, identity

\section{BEVEZETÉS}

Az európai iszlám vizsgálatakor érdekes színfoltot jelentenek a Balkán muszlim népességű országai, elsősorban Albánia, Koszovó és BoszniaHercegovina, ahol az Oszmán Birodalom térhódítása miatt már évszázadokkal ezelőtt meghonosodott a vallás. Bár a köztudatban a Balkán elsősorban a délszláv népek által lakott területet jelenti, az albánok kivételt jelentenek az etnikumukat és a nyelvüket is tekintve. A tudomány jelenlegi 
állása szerint az albánok nagy valószínűséggel az ókori illírek leszármazottai, nyelvük pedig igazi kuriózum: az indoeurópai nyelvcsaládba tartozik, viszont annak teljesen külön ágát képviseli, mivel nem rendelkezik közelebbi rokonnyelvvel. Az albánoknak két népcsoportja létezik, amelyek külön nyelvjárást beszélnek, északon a geget, délen pedig a tos₹kot. A mai albán irodalmi nyelv a toszkon alapul, de sok elemet átvettek gegből is. ${ }^{2}$ A vallási hovatartozás szempontjából is különböznek a szomszédos államoktól, mivel az albán népesség négy fó vallási felekezethez tartozik. A legutóbbi, 2011-es népszámlálás eredményei alapján az albánok 56,7 \%-a vallja magát muszlimnak, $10 \%$-a római katolikusnak, 6,8 \%-a ortodoxnak, 2,1\%-a pedig a bektasi szúfi rend követőjének. ${ }^{3}$ A vallási és etnikai hovatartozást tekintve az északi gegek inkább szunnita muszlimok vagy katolikusok, a déli tosækok pedig jellemzően a bektasi irányzat és az ortodoxia hívői. A mai albán állam a laïité francia modellt követi: nincsen egy meghatározott hivatalos államvallás, ugyanakkor tiszteletben tartják a vallások egyenlőségét és intézményi függetlenségét. $^{4}$

Tanulmányomban az albániai iszlámot fogom górcső alá venni, először a történeti háttér áttekintésével, majd a muszlim közösség aktuális helyzetének bemutatásával. Végül pedig arra szeretnék választ kapni, hogyan és mennyire szigorúan alkalmazzák az albániai muszlimok a saría házassági jogi szabályait. Az albániai iszlám vizsgálatakor azért tartom kifejezetten fontosnak az albániai muszlimok történetének feldolgozását, mert véleményem szerint az ország történelme során betöltött szerepük nagymértékben meghatározta egyrészt a nemzeti identitásuk alakulását, másrészt pedig a vallási, azon belül is az iszlám házassági joghoz való viszonyukat. Egyelőre még nem volt lehetőségem Albániában kvalitatív kutatásokat végezni, ezért a jelen tanulmányomat elsődleges és másodlagos források feldolgozásával és elemzésével írtam meg.

\section{TÖRTÉNETI ÁTTEKINTÉS}

A különböző hódítások ellenére az albán törzseknek az évszázadok folyamán sikerült megőrizniük törzsi közösségeiket, ugyanakkor állandó rivalizálás jellemezte őket. A széthúzásnak az egyik elsődleges oka a vallási megosztottságuk volt - a római katolikus és a görögkeleti albán fejedelem-

\footnotetext{
2 KEMENSZKY, 2010. 448-449.o.

${ }^{3}$ CIA WORD FACTBOOK, 2019.

${ }^{4}$ Elbasani, 2010. 4.o.
} 
ségek gyakran harcoltak egymás ellen. Az egység hiánya egyszerűvé tette az Oszmán Birodalom számára a Balkán meghódítását a XV. századra. Az oszmánok Albániát beolvasztották a birodalom közigazgatásába: két szandzsákra és tíz vilajetre osztották, melyeket török főurak irányítottak. ${ }^{5}$ Ezzel egyidejűleg elkezdődött az albánok iszlamizálása is. Az albán függetlenséget pár évre kiharcoló nemzeti hős, Szkander bég 1468-ban bekövetkező halálát követően ténylegesen kezdetét vette a teljes oszmán hódoltság kora.

Az Oszmán Birodalomban a társadalom egyrészt a vallási hovatartozás, másrészt a társadalmi osztályok szerint oszlott meg. Az alávetett népek áttért muszlim tagjai adókedvezményekben részesültek, sốt az iszlámra áttért családokat nem kötelezték a XVII. századtól bevett úgynevezett devşirmére (gyerekadó) sem. Ez azt jelentette, hogy török hivatalnokok néhány évente körbejárták az alávetett területeket, és egy-egy fiúgyermeket elszakítottak családjuktól, hogy Anatóliába vigyék őket és az iszlám tanításai szerint a Birodalomhoz hú janicsárokat képezzenek belőlük. Bár az Oszmán Birodalomban a hivatalnokok érdem szerint léphettek előre, a legtöbb posztot csak az iszlám hívei tölthették be. ${ }^{6}$ Ezek az intézkedések, illetve az erőszakos iszlamizálás vezettek ahhoz, hogy az albánok mintegy kétharmada áttért a szunnita iszlám hitre. ${ }^{7}$

Az oszmán időkben erősödtek meg Albániában a sæúfi rendek $^{8}$, azok közül is különösen a bektasi irányzat, amelynek ma Tirana a központja. ${ }^{9}$ A bektasi rend hivatalosan az iszlám szunnita ágához tartozik, azonban tanait tekintve közelebb áll a síta iszlámhoz. Merített a kereszténység hitelveiből, de indiai és iráni misztikus mozgalmak is hatást gyakoroltak rá. A bektasi irányzat előírásai nagymértékben eltérnek a hagyományos iszlám tanításoktól és vallásgyakorlattól. A teljesség igénye nélkül néhány példával ismertetem a fontosabb különbségeket. A bektasi hívők a ramadán helyett Ali fiainak tiszteletére böjtölnek, továbbá csak napkeltekor és napnyugtakor imádkoznak a napi ötszöri ima kötelezettségével szemben. Fő vallási vezetőik, a babâk

\footnotetext{
5 RÉTI, 1991. 18-21.o.

${ }^{6}$ KEMENSZKY, 2010. 453.o.

7 HeKA, 2013. 46.o.

${ }^{8}$ Szúfizmus: az iszlám misztika hiedelem- és szokásrendszere.

9 A bektasi rend központja 1925-ben került Tiranába, bár még ma is vitatott az albán és a török követők között, hogy hol van a rend valódi központja: Tiranában vagy a rend alapítójának a szülőhelyén, az anatóliai Haddzsi Bektasban (Hacıbektaşban), amelyet a nevére kereszteltek át.
} 
tartják az istentiszteleteiket, ahol a nők és a férfiak vegyesen foglalnak helyet. A nőknek nem teszik kötelezővé a kendő viselését, illetve a nők és férfiak minden szempontból egyenlőek és ugyanazok a jogok illetik meg őket. A fentieken kívül még az alkohol fogyasztását sem tiltják. Elismerik a tizenkét prófétát, Mózest, Máriát és Jézust, illetve több szentet. Valószínűleg az indiai hatás miatt a lélekvándorlásban is hisznek. ${ }^{10}$ Érdekesség, hogy Gül Baba is a bektasi rend tagja volt, akinek végső nyughelye a budai Rózsadombon található.

A Balkán népeire és különösen az albánokra jellemző az, hogy a nyugat- vagy még a kelet-európaiakhoz képest is később ébredtek nemzeti öntudatra. Ennek összetett és többrétü okai voltak. Az albánok többsége az azonos vallás miatt részben közösséget vállalt a megszálló törökökkel, illetve ragaszkodott a muszlimoknak járó privilégiumokhoz. A vallási megosztottság, a törzsi ellentétek, a paraszti lakosság elmaradottsága és a hegyekben való elszigeteltsége is mind hozzájárultak, hogy a XIX. század első felében a kisebb autonómiát követelő felkeléseiket leverték, és csak 1878-ban alakult meg az albán bégeket, kereskedőket és értelmiségieket tömörítő nemzeti ellenállást összefogó Prizreni Liga, amelynek eredeti célja még akkor sem a függetlenedés volt, hanem a széthulló Oszmán Birodalomban nekik járó kiváltságok megórzése. Csak az utolsó programjuk fogalmazta meg az Oszmán Birodalomtól való elszakadást. Bár a Liga a kezdetben sikeresnek bizonyult, 1881 végére az oszmánok mégis leverték a lázadásaikat és felszámolták a Prizreni Ligát. Ennek ellenére az albánok nem mondtak le nemzeti törekvéseikről, több felkelésben részt vettek és a XX. század első éveiben elkezdtek politikai köröket szervezni, illetve fejleszteni az albán irodalmi nyelvet. Végül 1912-ben alakult meg a független albán állam, viszont az albánoknak majdnem a fele a határokon kívülre szorult. Az albánok nemzeti mozgalma abból a szempontból kuriózumnak tekinthetô, hogy mind az iszlám, mind a katolikus és az ortodox vallásúak csatlakoztak hozzá, vagyis a nemzet és a vallás nem olvadt egybe, mint más Balkán országok esetében. A mai albán társadalomra is igaz, hogy a vallási megosztottság ellenére a nemzeti összetartozás és az egymás iránt tanúsított tolerancia jellemezi. ${ }^{11}$

Az albán államiság létrejöttekor nem jelöltek ki hivatalos államvallást, hanem létrehoztak három nemzeti egyházszervezetet. Az albán Muszlim Közösség (Xhemijeti Islamije) 1923-ban nyilvánította ki függetlenségét az

\footnotetext{
${ }^{10}$ KEMENSZKY, 2010. 465-468.o.

${ }^{11}$ HEKA, 2010. 144-146.o.
} 
Oszmán Kalifátustól, mivel az albánok minden kapcsolatot meg szerettek volna szüntetni a hanyatló Oszmán Birodalommal, illetve céljuk volt, hogy saját nemzeti vallási közösségeket hozzanak létre. ${ }^{12}$ Eleinte a bektasi rend is a Muszlim Közösség tagja volt, viszont a későbbiekben teljesen autonóm csoporttá vált saját vezetéssel és alapszabállyal. ${ }^{13} \mathrm{Az}$ Ortodox Keresztény Egyház szintén függetlenítette magát az isztambuli pátriárkától. Az Albán Katolikus Egyház viszont megtartotta szoros viszonyát a pápával. Az albánok vallási hovatartozását tekintve ekkor a szunniták tették ki a népesség 55\%-át, a bektasi rend követői a 15\%-át, az ortodoxok a 20\%-át, a katolikusok pedig a 10\%-át. A négy fő vallás mellett a török időkben több szúfi rend is meghonosodott az országban, de közel sem terjedtek el olyan széles körben, mint a bektasi irányzat. ${ }^{14}$

A két világháború között egy tekintélyes albán földesúr, Ahmet Zogu ragadta magához a hatalmat először belügyminiszterként, majd a köztársaság elnökeként, 1928-ban pedig királlyá koronáztatta magát. Ezután került sor az új szekularizált polgárjogi kódex hatályba lépésére, amely szerint a pénteki szabadnapot eltörölték, a többnejűséget betiltották, és megváltoztatták a házassági és öröklési jogot. Az új szabályok feszültségeket keltettek különösen a vidéki konzervatív muszlimok körében. Az államhoz hû Albán Muszlim Közösség viszont elfogadta a reformokat. A szekularizált Albániában a muszlim klérusnak már nem volt beleszólása a közéletbe. A kádik számára ez komolyan érzékelhető változásokat hozott, mivel az Ottomán megszállás hosszú évszázadai alatt bírókként, jegyzőkként és vallási hivatalnokokként jártak el, akik a házasságkötéseket, a születéseket, az elhalálozásokat és a közvitákat kezelték. A kormány nagymértékben csökkentette az iszlám szerepét az országban, ugyanakkor támogatta a Muszlim Közösséget abban, hogy az iszlám egyetlen hivatalos vallási képviselője és irányítója legyen Albániában. ${ }^{15}$

Annak ellenére, hogy I. Zogu király muszlim volt, a katolikus Apponyi Geraldine magyar grófnőt vette feleségül 1938-ban, akinek nem kellett áttérnie férje vallására, de házasságukat az iszlám szerint kötötték. A házasságkötéskor az imám szerepét az utolsó budai főmufti, Durics Hilmi Huszein töltötte be, aki szoros barátságban állt a királlyal. ${ }^{16}$

\footnotetext{
12 CLAYER, 2008. 129.o.

13 ELBASANI, 2010. 6.o.

${ }^{14}$ KEMENSZKY, 2010. 470-471.o.

15 JAZEXHI, 2017. 51-52.o.

16 LIPPAY, 1938. 1.o.
} 
1939-ben az olaszok kapitulációra szerették volna kényszeríteni az uralkodót, aki elmenekült az országból. Ezt követően az olaszok megszállták Albániát, majd 1941-ben hozzá csatolták a környező albán lakta területeket, Koszovót, Nyugat-Macedóniát és Montenegró déli sávját, létrehozva NagyAlbániát, a tengelyhatalmak egyik bábállamát. Ekkor egy állam fennhatósága alá került az összes albánok lakta terület. A Muszlim Közösség vezetői, akik eddig Zogu királyhoz voltak húségesek, szövetséget kötöttek a tengelyhatalmakkal: a fasisztákra és Mussolinira az afrikai muszlimok megmentőjeként tekintettek, míg a briteket az iszlám és a muszlimok ellenségeinek tartották. Azokat az imámokat, akik nem értettek egyet a Muszlim Közösség fasisztabarát politikájával, bebörtönözték és eltávolították a Közösség szervezetéből. ${ }^{17}$

A második világháború alatt a kommunista partizán ellenállóknak akik már 1941-ben létrehozták az Albán Kommunista Pártot ${ }^{18}$ - végül sikerült felszabadítaniuk az országot 1944-ben, viszont az önálló államnak már nem volt része se Macedónia albánok lakta nyugati része, se Koszovó. Két évvel később kikiáltották a népköztársaságot, majd Enver Hodzsa pártfőtitkár vezetésével elkezdték kiépíteni a szocializmust és a Balkán legelnyomóbb diktatúráját. ${ }^{19}$

A szocialista blokk kommunista államait az erôs vallásellenesség jellemezte a marxi dialektikus materializmuson alapuló ateizmus alapján. A vallási üldöztetés már rögtön a hatalomátvételt követően megkezdődött. ${ }^{20} \mathrm{~A}$ Muszlim Közösség vezetőjét elbocsátották, és Enver Hodzsa támogatójával helyettesítették. Egy kivételével betiltották a muszlim lapokat, a közösséget teljesen elszigetelték a muszlim világgal való kapcsolattartástól és szigorúan ellenőrizték az összes tevékenységüket az újonnan létrehozott Egyházi Ügyek Bizottsága által. Az imámok és muftik tevékenységét ellehetetlenítették, a hívőket pedig úgy megfélemlítették, hogy nem mertek mecsetbe járni. A pénteki szertartásokra, amelyeket párthivatalnokok cenzúráztak, az imámoknak külön engedélyt kellett kérniük a kommunista hivataloktól. Mindemellett az Albán Munkáspárt minden fronton propagandaháborút indított a vallások ellen. Az embereknek meg kellett változtatniuk iszlám nevüket. A muszlim vallási vezetőket reakciósként és burzsoáként bélyegezték meg, sokukat bebörtönözték, sôt kivégezték. A

17 JAZEXHI, 2017. 52-53.o.

18 RÉTI, 1991. 40.o.

${ }^{19}$ DiEnES, 2004. 26-27.o.

${ }^{20}$ KEMENSZKY, 2010. 478.o. 
kormány 1964-ben bezáratta az utolsó madrasszát (iszlám iskolát) Tiranában, majd összegyűjtötte az összes arab írásjelekkel íródott könyvet, hogy kartonként újrahasznosítsák őket. Az Albán Munkáspárt az utolsó csapást 1966-ban mérte a vallásokra, amikor egy tömegekhez intézett nyílt levélben elítélte a vallásokat és arra szólította fel az embereket, hogy támadják meg a vallási intézményeket. Ekkor már csak hat mecset múködött az országban. A Muszlim Közösség vezetője 1967 februárjában arra utasította az imámokat, hogy ne viseljék tovább a vallási öltözetüket és adják át az imádkozó helyeket és türbeket (szent sírokat) a népnek. A mecsetek csak péntekenként és hivatalos ünnepeken lehettek nyitva, nem lehetett semmilyen vallásos eseményt szervezni, végül az adhan (imára hívás) már péntekenként sem volt engedélyezett. 1967 áprilisában a Népgyúlés elnöksége elrendelte, hogy a vallási intézmények összes tulajdonát adják át a Kommunista Párt szövetkezeteinek és bizottságainak. Az 1967-es „kulturális forradalom” kínai mintára ment végbe. Az 1976-os alkotmány 37. cikke alapján Albánia a világ első hivatalosan is ateista állama lett: „Az állam nem ismer el semmilyen vallást, és támogatja az ateista propagandát annak érdekében, hogy az emberekben kialakítsa a tudományos materialista világ szemléletét." $21 \mathrm{Az}$ 1977-es büntetô törvénykönyv szerint a vallásos irodalom birtoklását és az istentisztelet bármely formáját háromtól tíz évig terjedő szabadságvesztéssel büntették, vagyis gyakorlatilag teljesen betiltották a vallási tevékenységet. Az Albán Muszlim Közösség megszűnt létezni, a muszlim kulturális és rituális hagyományok gyakorlatilag elvesztek az 1990-ig tartó, több, mint húsz éves üldöztetés folytán. Persze néhány túlélő imám titokban továbbra is tartott istentiszteletet az otthonaikban zárt csoportoknak. ${ }^{22}$ Fontosnak tartom megjegyezni, hogy az albánok által hangoztatott vallási tolerancia részben abból is fakad, hogy a kommunista rezsim alatt az összes vallási közösséget ugyanúgy elnyomták, így egyfajta szolidaritás alakult ki egymás irányába.

A kommunista rezsim bukásával 1990 decemberében visszaállították a vallásszabadságot. A hívők már novemberben ezrek részvételével katolikus misét tartottak Shkodrában, majd pár héttel később, november 16-án 60.000 muszlim gyűlt össze a szintén shkodrai Lead mecsetben (Xhamia e Plumbitmagyar nyelven Ólom-mecset), ahol deklarálták az Albánia Muszlim Közösségének (a továbbiakban: AMK) újbóli felállítását. Az összes vallási szervezet, köztük az AMK is többrétú nehézségekbe ütközött az anyagi és

\footnotetext{
21 ANDERSEN, 2005. (ford. Baranyi Emese Zsuzsanna)

22 JAZEXHI, 2017. 54-56.o.
} 
szellemi struktúrájuk újjáépítése során. Az AMK-nak nem volt semmilyen tulajdona, infrastruktúrája, költségvetése és valójában hívei sem, mivel a több évtizedes üldöztetés és elnyomás következtében az albánok új generációja már nem tartotta magát muszlimnak, annak ellenére, hogy apáik még azok voltak. Bár a mecsetek kapui 1991-ben kinyíltak, az emberek többsége nem tudta, hogy kicsoda Allah és Mohamed. Tehát az AMK-nak gyakorlatilag a semmiből kellett újból létrehoznia a vallási vezetéshez nélkülözhetetlen feltételeket: szüksége volt mecsetekre, iszlám iskolákra (madrasszákra) és legfőképpen hívőkre. Ezeket a feltételeket csak külföldi támogatásra támaszkodva tudta megteremteni. ${ }^{23}$ A rendszerváltozást követően számtalan külföldi (pl. török, európai, arab, amerikai) nonprofit szervezet jelent meg az országban, de az AMK közvetlenül is kapott támogatást az arab országokon (például Szaúd-Arábia, Kuvait, Egyiptom, Egyesült Arab Emirátusok, Líbia, Jemen, Algéria) kívül Törökországtól, Irántól, Pakisztántól és Malajziától is. Imámokat és tanárokat képeztek ki, hogy hirdessék az iszlámot Albánia-szerte. A szaúdiak az albán nyelvre lefordított Koránt terjesztették az országban, muszlim szervezetek kórházakat, egészségügyi központokat és vízellátást építettek ki. Hogy biztosítsák a jövő számára a vallási vezetőket, fiatal albánoknak ösztöndíjakat ítéltek meg, hogy arab egyetemeken tanulhassanak. Emellett egyre több madrassza alakult szintén külföldi forrásokból, amelyek egy része ma sem tartozik az AMK felügyelete alá, hanem például a török Gulen Mozgalomhoz kapcsolható alapítványok működtetik őket. ${ }^{24}$ Kiemelendő, hogy a rendszerváltozás óta Albániában rengeteg új mecset épült, szintén külföldi finanszírozásból: kezdetben jellemzően az arab államok voltak a donorok, a 2000-es évektől pedig inkább Törökország. Ma már több, mint 500 mecset található az országban, amelyek jelentősen meghatározzák az albán tájképet a távolról is szembetűnő minaretjeiknek köszönhetően. ${ }^{25}$

A szocialista rezsim összeomlása után a bektasi rend is elkezdte újjászervezni magát, 1991-ben megnyitották a fő tek.kêjüket (a sqúfi istentisztelet helye) Tiranában. A bektasiak viszont nehezebb helyzetben voltak, mint a szunnita közösség, mivel nem számíthattak a muszlim világ támogatására. Segítséget Törökországból, a koszovói és a macedón bektasi közösségtől, az amerikai egyesült államokbeli és ausztráliai albán diaszpórától, illetve Irántól kaptak. Jellemző, hogy a szunnita muszlim

23 Uo. 56-57.

${ }^{24}$ ELBASANI, 2010. 6-7.o.

25 BICKERT, 2018. 102-103.o. 
közösség kérdőre vonja a bektasi rend önállóságát, és a szunnita irányzaton belüli dervisrendnek tartják. Az 1993-ban megrendezett Bektasi Világkongresszuson viszont a bektasiak kinyilvánították, hogy a szunnitától teljesen független rendként értelmezik magukat. ${ }^{26} \mathrm{~A}$ bektasiak nagy hangsúlyt fektetnek az oktatás és a kultúra fejlesztésére. Az albánok úgy tekintenek a bektasi rendre, mint az iszlám demokratikus, liberális, toleráns, befogadó és hazai irányzatára. ${ }^{27}$

A fiatal albán demokráciában egészen az 1990-es évek végéig nem volt rendezve a vallások és az állam kapcsolata: az ad hoc megoldások és modus vivendi volt a jellemző. Az iszlám térnyerését támogató arab szervezetek kontroll nélkül tevékenykedtek az országban, végső célként kitűzve egy albán iszlám állam létrejöttét. 1998-ra világossá vált, hogy az állam laissez-faire politikája nem megfelelő a vallási tevékenységek állami felügyeletére. Az 1997-ben megválasztott Szocialista Párt nekilátott az iszlám segélyszervezetek szisztematikus ellenőrzéséhez, illetve az amerikai FBI-jal (Federal Bureau of Investigation) és európai terroristaellenes hivatalokkal együttmúködve biztonsági intézkedéseket foganatosított, amelyek a legaktívabb arab alapítványok bezárásához és az alkalmazottjaik kiutasításához vezettek. Ez a folyamat a 2001. szeptember 11-ei terrortámadások után is folytatódott az amerikaiak terrorizmus elleni háborújának támogatásaként. Szükségessé vált egy olyan keretrendszer kialakítása, amely formálisan lefekteti a vallási közösségek jogait és az őket érintő korlátozásokat, illetve viszonyukat az állammal. Az 1998-as albán alkotmány részletesen kidolgozta az állam és vallási szervezetek közötti együttmúködés feltételeit. Kiemelte a vallásszabadság elvét, az állam semlegességét és az állam és az egyházak közötti kölcsönös kooperáció fontosságát a közjó érdekében. Az államnak nincsen hivatalos vallása, ugyanakkor tiszteletben tartja az összes vallási közösség egyenlőségét. Az állam felügyelő szerepét úgy biztosítják, hogy a vallási szervezeteket nyilvántartásba veszik. A vallási szervezeteket az új alkotmány jogi személyiséggel ruházta fel. Az alkotmány rendelkezéseit kiegészítve a 2001-es nonprofit szervezetekről szóló törvény meghatározta, hogy a vallási szervezeteknek a Tiranai Bíróságon kell regisztrálniuk magukat, amely során automatikusan ellenőrzik, hogy az adott szervezet megfelel-e minden szempontból az állami jogszabályoknak.

\footnotetext{
${ }^{26}$ KEMENSZKY, 2010. 482.o.

${ }^{27}$ ELBASANI, 2010. 8.o.
} 
A bevezetésben már említett Kulturális Bizottságot 1999-ben hozták létre, amelyet egy semleges köztisztviselő az államot képviselve vezeti. Az új rendszerben az ún. tradicionális vallásokat - a szunnita iszlámot, a bektasi rendet, a római katolicizmust és az ortodox kereszténységet - képviselő szervezetek különleges privilégiumokat kaptak, amelyek megkönnyítik az állam számára a velük való együttmüködést és a vallási tevékenységek felügyeletét. A kitűntetett tradicionális felekezeteket egyetlen központi szervezet képviselheti, amely jogosult az állammal való kapcsolatuk részleteit szabályozó kétoldalú megállapodások megtárgyalására. Az albániai muszlimokat a már sokat tárgyalt Albánia Muszlim Közössége fogja össze, amely az egyetlen hivatalos hatóságként felelős a muszlimok adományainak kezeléséért, az infrastruktúra fenntartásáért, a vallási oktatás megszervezéséért és a muszlim hívők képviseletéért a nyilvánoság előtt. Az 1990-es években a gomba módjára szaporodó, külföldi finanszírozású iszlám szervezetek mellett az AMK nem tudta érvényesíteni koordinációs központi szerepét mint ernyôszervezet, de az 1998-as szabályozásoknak köszönhetően megerősödött a központi helyzete és szerepe. Közvetlenül csak az AMK tud az állammal tárgyalásokat folytatni, képviselteti magát a Kulturális Bizottságban, szabad hozzáférése van az állami médiához és pénzügyi támogatást kap az államtól. Az AMK az albán kultúra és hagyományok védelmezőjének tartja magát, és egy nemzeti, hagyományosan albán, liberális, befogadó iszlámot képvisel. Ezt azért is fontos kihangsúlyozniuk, mert az albán közéletben és politikában jellemző, hogy az európai integrációs folyamatok sikertelenségéért az oszmán múltat és az ország iszlám vallású államként való megbélyegzését okolják, ezért gyakran előfordul az albán politikusok és közszereplők retorikájában az iszlámtól való elhatárolódás. ${ }^{28}$

\section{AZ ISZLÁM HÁZASSÁGI JOGI SZABÁLYOK ALKALMAZÁSA AZ ALBÁNIAI MUSZLIMOK KÖRÉBEN}

Eddigi kutatómunkám alapján arra a megállapításra jutottam, miszerint az albánokra korábban sem volt jellemző az, hogy szigorúan ragaszkodjanak a vallási elő́rásokhoz. Az albánok nagy része például korábban sem követte az alkoholfogyasztásra vonatkozó tilalmat, nem minden esetben gyakorolta a napi imát (namaz), illetve a rituális böjtöt, a

${ }^{28}$ ELBASANI - PUTO 2017. 10-20.o. 
ramadant pedig alig tartotta. Természetesen minden háztartásban megtalálható a Korán, segítik a szegényeket, az iszlám szokások szerint temetik el a halottjaikat és elzarándokolnak Mekkába vagy a szentek sírjaihoz. ${ }^{29}$ Összességében igyekeznek a vallási tanításoknak megfelelően élni a mindennapokban és a vallási szertartások során törekednek az iszlám hagyományok követésére.

A Nyugat-Európában élő muszlim népesség kapcsán egyre többet hallhatunk az iszlám családjogi szabályok alkalmazásának lehetőségeiről egy multikulturális társadalom keretein belül. Erre a legelőrehaladottabb példa az Egyesült Királyságban működő iszlám jogi döntőbírósági rendszer. A Muszlim Választottbíróságot (Muslim Arbitration Tribunal, a továbbiakban: MAT) 2007-ben hozták létre, hogy múködőképes alternatívát nyújtson a muszlim közösség tagjainak, akik a vitákat a szent iszlám törvény szerint kívánják rendezni. Az 1996. évi Választottbírósági Törvény hatálya alatt múködő MAT egy hatékony és egyedülálló alternatív vitarendezési szervezet, amely az angol jogrendszer keretein belül alkalmazza az iszlám jogot. ${ }^{30}$ Ezek a saría bíróságok jellemzően csak családjogi estekben ítélkeznek, többnyire válást bonyolítanak le az iszlám jog szerint. A nyugateurópai muszlim közösségekkel szemben Albániában eddig nem volt arra igény, hogy az iszlám jogalkalmazásra külön rendszert állítsanak fel. ${ }^{31}$ Ennek okai valószínúleg a posztkommunista múltból következnek, illetve az Európai Unióhoz való csatlakozási törekvésekkel is összefüggésben vannak.

Manapság csak kevés albán muszlim köt házasságot az iszlám szerint. ${ }^{32}$ Ugyanakkor megfigyelhető az a jelenség, hogy az iszlám szerinti házasságra, a nikabra, csak mint eljegyzésre tekintenek, vagyis a párok a nikahval egyidőben nem kötnek polgári házasságot. A nikah alkalmával a felek egy szerződést írnak alá, így vallási szempontból házastársakká válnak, vagyis azt követően felügyelet nélkül lehetnek egymás társaságában. A szekularizált államokban, mint Albánia, ahol hivatalosan csak a polgári házasságkötést fogadják el, gondot jelenthet, ha a párok csak az iszlám szerint kötnek házasságot. Ezért az albán imámokat aggasztja ez a tendencia, és híveik körében hangsúlyozzák, hogy a nikah a házasságkötéssel egyenlő, és a lefolytatását követően a felek házastársakká válnak. Sok imám megköveteli, hogy a nikah lefolytatása előtt a pár mutassa be a házassági

\footnotetext{
${ }^{29}$ DOJA, 2006. 88.o.

${ }^{30}$ Muslim Arbitration Tribunal, 2019.

${ }^{31}$ Bougarel, 2005. 15.o.

32 JAZEXHI, 2012. 10.o.
} 
anyakönyvi kivonatát, amelyet az önkormányzati hivatal bocsátott ki a polgári házasságkötéskor, így megakadályozva az anomáliát, miszerint az iszlám szerint házastársaknak tekinthetőek, de az állami jog szerint nem. Ennek a szemléletnek az egyik oka, hogy az iszlám jog elfogadja a nem muszlim szervezetek által kibocsátott házassági szerződéseket is. Például ha egy pár katolikus templomban esküdött, majd később áttértek az iszlámra, nem kell újból házasságot kötniük az iszlám jog szerint. Ennek értelmében a polgári házasságkötést is érvényesnek tekinti az iszlám jog. A rendszerváltás után ezért nem kellett a muszlim híveknek újból házasságot kötniük.

A másik ok, amiért az imámok támogatják a polgári házasságkötést a nikeah mellett, az esetleges váláskor előforduló problémás kérdések rendezése. A nikeah egy vallási rituálé, amely kapcsán az albán imámoknak semmilyen eszközük nincs a válás következményeinek kikényszerítésére. Bár egy polgári peres eljárás eredménye eltérhet az iszlám törvényben megfogalmazottaktól, mégis van kényszerítő ereje. Az imámok fő aggodalma a nők számára biztosított jogvédelem hiánya olyan esetekben, amikor a válni kívánó nőnek a bíróság nem tud jogi és pénzügyi védelmet nyújtani a polgári házasságkötés elmaradása miatt. Olyan rendszer hiányában, amelyben az iszlám jog a házasság felbontásából eredő kötelezettségeket kikényszeríthetné, a szekularizált állam törvényei biztosítékokat és kötelezettségeket írnak elő a válás esetén, még akkor is, ha ezek a jogi kötelezettségek nem egyeznek meg az iszlám házassági jogban foglaltakkal. Előfordul azonban, hogy az imámokat közvetítőnek kérik fel (kivétel nélkül nôk) házassági viták rendezésére. Ezeket a mediációs eljárásokat nem fogadják el a bíróságok és nincsen jogi erejük, a döntéseik csupán tanácsadásként értelmezhetők, amelyet a pár vagy megfogad, vagy elutasít. Az imámok azonban felhívják a figyelmüket arra, hogy bár az iszlám engedélyezi a válást, Allah szemében a válás a legrosszabb a megengedett dolgok között, és ha a felek látnak rá módot, akkor meg kell próbálniuk megmenteni a házasságukat. ${ }^{33}$

Érdekes kitérni az iszlám házassági jogban kiemelkedő szerepet betöltött mahr jogintézményére. Az érvényes iszlám házassági szerződés egyik elengedhetetlen eleme a mahr mértékének meghatározása. A mahr nélkül kötött házasságok automatikusan érvényüket vesztik. A mahrt a vőlegény vagy a vőlegény apja, illetve családja adja a menyasszonynak a házasságkötés alkalmából kötelező jelleggel, és célja, hogy a nőnek pénzügyi

33 SINANI, 2013. 116-117.o. 
függetlenséget biztosítson elsősorban a férje halála vagy válás esetére, mivel a saría nem ismeri a házassági vagyonközösség fogalmát. ${ }^{34}$ A mahrt a mennyasszony gyakran két részletben kapja meg. A házassági szerződés megkötésekor kapja meg az első részt, amely a feleség kizárólagos tulajdona már a házasság alatt, és arra költheti, amire csak kívánja. A késleltetett mabr összegéről általában szintén megegyeznek a házassági szerződésben, azt viszont a feleség egy, a szerződésben meghatározott késôbbi időpontban kapja meg. A késleltetett mahr jellemzően nagyobb összegü, mint az azonnali mahr, mivel ez szolgálja a nô megélhetését a férje halálakor vagy a válás után. $^{35} \mathrm{~A}$ muszlim világban a váláskor általában a késleltetett mahrral kapcsolatban alakulnak ki viták a felek között, különösen, ha nagyobb összegről vagy vagyonról van szó. Ezzel szemben az albán muszlimok körében kis jelentősége van a mabrnak. A mahr teljesen kikopott az albán társadalmi gyakorlatból 1967 után a kommunista rezsim vallásokkal szemben tanúsított elnyomó politikájának az eredményeképpen, de az 1990-es években újra bevezették. Az imámok új generációja - akik a Közel-Keleten tanultak iszlám egyetemeken - támogatták és terjesztették a mabr gondolatát, ugyanakkor arra kérték a híveket, hogy kerüljék a nagy összegü mahr kikötését, amellyel elanyagiasítanák a házasság intézményét. Mohamed prófétát idézve hangoztatták, hogy akár egy gyűrű is megfelelő mahr lehet. A mai albán muszlimok között elterjedt, hogy a gyűrűk cseréjének amúgy is bevett szokásával teljesítik a mahr kötelezettségét. Ez a gyakorlat egy kompromisszumnak is tekinthetô az új fiatal generációs muszlimok és a kommunizmusban nevelkedett szüleik között. A mahr teljesítésének másik elterjedt formája az albánok között, hogy a vőlegény ígéretet tesz a menyasszonynak, hogy állja a mekkai zarándoklatának (haddæs) a költségeit. Az albán imámok a mahr teljesítésének ezt a formáját késleltetett mahrnak tekintik. Ennek ellenére példátlan, hogy egy válófélben levő nő a férjén követelné a haddzs költségeit mint késleltetett mahrt. ${ }^{36}$

Az imámok a házassággal kapcsolatos vitás ügyekben az állami joghoz való alkalmazkodást ajánlják. Általánosságban megállapítható, hogy a hívő muszlimok a jogalkalmazás tekintetében el szeretnék kerülni a szekularizált állammal való konfrontálódást. ${ }^{37} \mathrm{Az}$ állammal való szembenállás csak a politikai részvétellel kapcsolatban mutatkozik. Az albán imámok nagy része

\footnotetext{
${ }^{34}$ HEKA, 2012., 299-305.o.

35 SPENCER, 2011. 8.o.

36 SINANI, 2013. 118.o.

37 Uo. 118-119.o.
} 
az 1990-es években szaúd-arábiai egyetemeken tanult, ahol nem támogatják az imámok politikai aktivitását. Csak elenyésző azoknak az albán imámoknak a száma, akik nem vesznek részt a választásokon, mivel nem szeretnének támogatni egy olyan államot, amely nem Allah törvényein alapszik. Az albán muszlimok összességében viszont támogatják a vallásoknak széles szabadságokat biztosító szekularizált államberendezkedést. Két témakörben tüntettek eddig: a muszlim diáklányok kendőviselésére irányuló tilalom és Teréz anya ${ }^{38}$ túlzott népszerűsítése ellen. Ezeken kívül még a mecsetépítések körül alakult ki a muszlim közösség és az állam között vita. ${ }^{39}$

A téma kapcsán érdemesnek tartok egy bekezdést szentelni a katolikus albánok sajátos, a mai napig (bár bizonyos téren csak marginálisan) használatos, szintén nem az állami jogrendszert képező szokásjogra (Kanuni $i$ Leke Dukagjinit). Az észak-albániai hegyekben, Nyugat-Macedóniában, Koszóvóban és Kelet-Montenegróban az albánok az oszmán megszállás alatt $^{40}$ is alkalmazhatták saját törzsi szabályrendszerüket, ${ }^{41}$ amely az évszázadok során szájhagyomány útján terjedt, és csak a XX. század elején jegyezte le egy ferences szerzetes és néprajzkutató, Shtjefën Konstantin Gjeçovi-Kryeziu. ${ }^{42}$ Az eredetét tekintve valószínúleg ókori illír törzsi gyökerekhez vezethető vissza. A Kanunban szerepel többek között a vérbosszú intézménye is, amelyet az utóbbi időben is követnek az albánok. Csak a férfiakat érinti, a nők sértetlenek. ${ }^{43}$ Becslések szerint ma is több ezer ember, köztük sok gyerek, él teljes elszigeteltségben a vérbosszútól rettegve. $^{44}$ Ebből adódik, hogy az északi hegyekben élő katolikus közösségekben jellemzően a nők dolgoznak és tartják el a családjukat. Természetesen a vérbosszú intézményén kívül a Kanun számos más rendelkezést is tartalmaz: egy átfogó, a társadalmi berendezkedés minden szintjét szabályozó kódexről van szó. A Kanunt az albánok nemzeti örökségükként tartják számon, ami túlvészelte az ottomán megszállást és

\footnotetext{
38 Kalkuttai Szent Teréz albán származású római katolikus apáca, aki a Nobel-békedíj (1979) mellett számos kitüntetést kapott az indiai Kolkata szegénynegyedeiben végzett áldozatos munkájáért.

${ }^{39}$ Uo. 119-120.o.

40 Létrehoztak egy irodát is, amely a Kanun törvényeit próbálta egyeztetni az oszmánok szabályaival úgy, hogy azok ne sértsék az albánokat. (DIENES: i. m. 15.)

${ }^{41}$ HEKA, 2010. 143.o.

42 SINANI, 2013. 112.o.

${ }^{43}$ DIENES, 2004. 14-18.o.

${ }^{44}$ EURONEWS, 2016.
} 
lehetetlenné tette, hogy az északi területeken bevezessék a saríat. A mai Albániában az állami jogrendbe nincsenek beépítve se a saría, se a Kanun rendelkezési, mindkettő szabályrendszer alkalmazása esetleges az adott vallási közösségben.

\section{KONKLÚZIÓ}

Tanulmányomban végigkísértem az iszlám térnyerését az albán történelem során. Az ötszáz éves oszmán hódoltság alatt az albánok nagy része, vagyis több, mint háromnegyede áttért az iszlámra. Ennek elsődleges oka az volt, hogy az Ottomán Birodalomban a muszlimok privilégiumokban részesültek: adókedvezményeket kaptak, magasabb hivatalnoki posztokat tölthettek be, földhöz jutottak. A hagyományos szunnita iszlám mellett több szúfi rend is elterjedt Albániában, a bektasi irányzat nyerte meg a legtöbb hívőt és honosodott meg, olyannyira, hogy a központjuk ma Tiranában található és az irányzatot az albánok saját nemzeti vallásukként tartják számon. Az északi hegyekben elő katolikus albánoknak az elszigeteltségükből adandóan sikerült megőrizniük hagyományaikat és saját törzsi szokásjogukat, a Kanunt, amelyet a mai napig alkalmaznak. A független Albániát 1912-ben kiáltották ki, ekkor a fő vallási felekezetek - az iszlám (55\%), a bektasi $(15 \%)$ és az ortodox $(20 \%)$ - a római katolikusok $(10 \%)$ kivételével saját nemzeti vallási közösségeket alakítottak ki. 1923-ban alakult meg az Albánia Muszlim Közössége, amely jelenleg is összefogja az albániai muszlimokat. A második világháborút követően a kommunista állam elnyomta, majd az 1967-es „kulturális forradalmat” követően be is tiltotta a vallásokat, végül az 1976-os alkotmányban foglaltak szerint Albánia lett a világ első ateista országa. 1990-ben megbukott a kommunista rezsim, de a 23 évnyi teljes vallástilalom következtében szinte a semmiből kellett újraépíteni az albánok vallásosságát és vallási szervezeteit. Külföldi donorok, elsősorban arab államok segítették az Albánia Muszlim Közösségét: mecseteket építettek, madrássðâkat nyitottak, arab egyetemekre ösztöndíjakat ítéltek a fiatal albánoknak és hittérítőket foglalkoztattak az országban. Az állam és a vallási közösségek közötti viszonyt az 1990-es évek végén rendezték, amikor francia példára megvalósult az albán laïcité, vagyis egy szekularizált államberendezkedés, ahol nincsen egy meghatározott államvallás, de az állam egyformán tiszteletben tartja az összes vallást. A négy fő vallási közösséggel szoros együttmúködésen alapuló, a közjót támogató struktúrát építettek ki. 
A tanulmányom második fejezetében az albán muszlimok viszonyát vizsgáltam az iszlám házassági jogi előírásokhoz. Az albánok a szocializmus előtt sem követték szigorúan a vallási szabályokat, hiszen a megszálló birodalom vallását vették át a privilégiumok miatt vagy kényszer hatására. A szocializmus alatt a vallási érzület több évtizedes elnyomása ezt a hozzáállást csak erősítette. Az iszlám házassági jogot manapság az albán muszlimok lazán értelmezik: a nikaht (iszlám jog szerinti házasság) inkább csak eljegyzésként tartják számon, a férj által kötelező jelleggel a feleségének biztosítandó nászadományt, a mahrt, pedig az amúgy is szokásos gyűrú átadásával elintézettnek tekintik. Nem mutatták ki a szándékukat arra, hogy az állami jogrendszerrel párhuzamosan az iszlám jogot alkalmazó döntőbíróságokat hozzanak létre. Általában kerülik az állami joggal való konfrontálódást, és alkalmazkodnak ahhoz. Ennek ellenére az utóbbi bő évtizedben támadásoknak vannak kitéve. Az albán politikusok egy része gyakran az ország iszlámként való megítélését és ottomán múltját az Európai Unióhoz való integrációs folyamatok akadályaként emlegeti. Az albán politikai elit iszlám-ellenes retorikája identitásdilemmához vezetett az albániai muszlimok körében, akik azt szeretnék elérni, hogy a saját országukban ne úgy tekintsenek rájuk, mintha idegenek lennének, illetve el szeretnék kerülni a társadalmi marginalizálódást és kivívni az iszlámnak a nemzeten belül az azt megillető helyet.

\section{FELHASZNÁLT IRODALOM}

Andersen, BJoern (2005): The Constitution Of The People's Socialist Republic Of Albania of 1967. Elérhető:

http://bjoerna.dk/dokumentation/Albanian-Constitution-1976.htm (Letöltve: 2019. április 12.)

BICKERT, MATTHIAS (2018): Re-sanctification of Space in Albania - The case of Sunnni Islam. In Balkan and Baltic States in United Europe Histories, Religions and Cultures II, 95-120. Elérhető:

https://www.academia.edu/38224424/Resanctification of Space in Albania - The case of Sunnni Islam (Letöltve: 2019. március 11.)

Bougarel, Xavier (2005): The Role of Balkan Muslims in Building a European Islam. In EPC Issue Paper No. 43, 2005. Elérhető: https://www.researchgate.net/publication/32230189 The Role of Bal 
kan Muslims in Building a European Islam (Letöltve: 2019. október 25.)

CIA WORD FACTBOOK: Albania (2019). Elérhető:

https://www.cia.gov/LIBRARY/publications/the-world-

factbook/geos/al.html (Letöltve: 2019. április 9.)

Clayer, NATHALIE (2008): Behind the veil. The reform of Islam in Interwar Albania or the search for a 'modern' and 'European' Islam. In Clayer, NATHALIE - GERMAIN, ERIC szerk.: Islam in Inter-War Europe, 2008, London, Hurst Publishers Ltd, 128-155. Elérhető: https://www.academia.edu/14608381/Behind the veil. The reform o f Islam in Inter-

war Albania or the search for a modern and European Islam (Letöltve: 2019. március 11.)

Dienes TiBor (2004): Albánia, Budapest, Hibernia Nova Kiadó.

DojA, AlBerT (2006): A Political History of Bektashism in Albania. In Totalitarian Movements and Political Religions, Vol. 7, No. 1, 2006, 83107. Elérhető: https://halshs.archives-ouvertes.fr/halshs00425475/document (Letöltve: 2019. április 12.) DOI azonosító: https://www.tandfonline.com/doi/abs/10.1080/14690760500477919

Elbasani, ArolDA - PUTO, ARTAN (2017): Albanian-Style Laïcité: A Model for a Multi-Religious European Home? In Journal of Balkan and Near Eastern Studies, Vol. 19(1). Elérhető:

https://papers.ssrn.com/sol3/papers.cfm?abstract id $=2898902$ (Letöltve: 2019. március 11.) DOI azonosító: DOI/10.1080/19448953.2016.1201994

ElBASANI, AROLDA: Religion and Democratization in Post-Communist Albania: Is it Possible to Be Islamic, Democratic and European at the Same Time? (2010). In American Political Science Association 2011 Annual Meeting Papers. Elérhető: https://papers.ssrn.com/sol3/papers.cfm?abstract id=1902010 (Letöltve: 2019. március 11.)

EURONEWS (2016): Az ország, ahol még él a vérbosszú intézménye, 2016. október 21. Elérhető: https://hu.euronews.com/2016/10/21/az-orszagahol-meg-el-a-verbosszu-intezmenye (Letöltve: 2019. április 13.) HEKA LÁSZLÓ (2010): Etnikai, vallási és politikai konfliktusok a Balkán térségben, II. rész Társadalmi, etnikai, vallási és politikai viszonyok a Balkán térségben, Szeged, Pólay Elemér Alapítvány. 
HEKA LÁSZLÓ (2013): A Balkán országainak intézmény- és jogrendszere, Szeged, Pólay Elemér Alapítvány.

HEKA LÁszLÓ (2012): Vallási jogrendszerek, Szeged, Pólay Elemér Alapítvány.

JAZEXHI, Olsi (2017): Albania. In RAČIUs, EGDŪNAS - ZHELÍȦKOVA, ANTONINA szerk.: Islamic Leadership in the European Lands of the Former Ottoman and Russian Empires: Legacy, Challenges and Change, BRILL, 2017, 45-67. Elérhetô:

https://www.academia.edu/36121842/A short history of the instituti on of Islam in Albania (Letöltve: 2019. március 11.) DOI azonosító: https://doi.org/10.1163/9789004352681

JAZEXHI, OLSI (2012): Albania. In Yearbook of Muslims in Europe, Volume 4, Brill, 2012. 1-15. DOI azonosító:

https://doi.org/10.1163/9789004234499 002

KEMENSZKY ÁGNES (2010): Az európai muszlim közösségek színfoltja: a balkáni muszlimok. In ROSTOVÁNYI ZsOLT szerk.: Az iszlám Európában, Az európai muszlim közösségek differenciáltsága. Budapest, Aula Kiadó. 447-485.

LIPPAY GYULA szerk. (1938): A budai főmufti adja össze mohamedán rítus szerint Zogu királyt és Apponyi Geraldine grófnőt, Budai Napló 36. évfolyam, 4. szám, Budapest. Elérhető: https://library.hungaricana.hu/hu/view/FSZEK HelyiLapok BudaiNa plo 1938/?pg=32\&layout=s\&query=Zogu (Letöltve: 2019. április 10.) MuSLIM ARBITRATION TRIBUNAL (2019). Elérhető:

http://www.matribunal.com/history.php (Letöltve: 2019. április 12.) RÉTI GYÖRGY (1991): Albánia, Győr, Panoráma.

SiNANI, BESNIK (2013): Albania and Kosovo, The Return of Islam in South-East Europe: Debating Islam and Islamic Practices of Family Law in Albania and Kosovo. In BERGER, MAURITIUS S. szerk.: Applying Shari'a in the West, Facts, Fears and Future of Islamic Rules on Family Relations in the West, 2013, Leiden University Press, 111-123. Elérhető: http://www.oapen.org/search?identifier=617551 (Letöltve: 2019. április 3.). DOI azonosító: 10.26530/OAPEN 617551

SpenCER, KATHERINe (2011): Mahr as Contract: Internal Pluralism and External Perspectives. In Oñati Socio-Legal Series, 2011/Vol. 1, No. 2. Elérhetô:

https://papers.ssrn.com/sol3/papers.cfm?abstract id=1898527 (Letöltve: 2018. november 17.) 